Article

\title{
Proposal of an Initial Environmental Management and Land Use for Critical Cemeteries in Central Ecuador
}

\author{
Geomara Flores Gómez ${ }^{1, *(\mathbb{D})}$, Tania Crisanto-Perrazo ${ }^{1, *(\mathbb{D})}$, Theofilos Toulkeridis $1, * \mathbb{D}$, Greta Fierro-Naranjo ${ }^{2}$, \\ Paulina Guevara-García ${ }^{1}\left(\mathbb{D}\right.$, Eduardo Mayorga-Llerena ${ }^{3}$, Diego Vizuete-Freire ${ }^{4}\left(\mathbb{D}\right.$, Esthela Salazar ${ }^{1}(\mathbb{D})$ \\ and Izar Sinde-Gonzalez ${ }^{1}$ (D)
}

Citation: Flores Gómez, G.;

Crisanto-Perrazo, T.; Toulkeridis, T.;

Fierro-Naranjo, G.; Guevara-García,

P.; Mayorga-Llerena, E.;

Vizuete-Freire, D.; Salazar, E.;

Sinde-Gonzalez, I. Proposal of an

Initial Environmental Management

and Land Use for Critical Cemeteries

in Central Ecuador. Sustainability

2022, 14, 1577. https://doi.org/

$10.3390 /$ su14031577

Academic Editor: Hone-Jay Chu

Received: 14 December 2021

Accepted: 26 January 2022

Published: 29 January 2022

Publisher's Note: MDPI stays neutral with regard to jurisdictional claims in published maps and institutional affiliations.

Copyright: (c) 2022 by the authors. Licensee MDPI, Basel, Switzerland. This article is an open access article distributed under the terms and conditions of the Creative Commons Attribution (CC BY) license (https:/ / creativecommons.org/licenses/by/ $4.0 /)$.
1 Department of Earth Sciences and Construction, Universidad de las Fuerzas Armadas ESPE, Sangolquí 171103, Ecuador; pvguevara@espe.edu.ec (P.G.-G.); eesalazar1@espe.edu.ec (E.S.); iisinde@espe.edu.ec (I.S.-G.)

2 Escuela Politécnica Nacional, Environmental Research and Control Center, Quito 170525, Ecuador; greta.fierro@epn.edu.ec

3 Faculty of Chemical Sciences, Universidad Central del Ecuador, Av. Francisco Viteri and Gato Sobral, Quito 170103, Ecuador; emayorga@uce.edu.ec

4 Instituto Superior Tecnológico Sucre, Higher Technology in Environmental Management, Quito 170129, Ecuador; dvizuete@tecnologicosucre.edu.ec

* Correspondence: geflores4@espe.edu.ec (G.F.G.); ttcrisanto@espe.edu.ec (T.C.-P.); ttoulkeridis@espe.edu.ec (T.T.); Tel.: +593-99-528-7520 (G.F.G.); +593-982085917 (T.C.-P.); +593-987001807 (T.T.)

\begin{abstract}
Cemeteries are sites for the final disposal of human bodies that constitute a source of contamination of soil and water as a result of the cadaveric decomposition generated. The current research performed an initial study on the contamination of soil and water due to the influence of cemeteries and verified compliance with the legislation regulating land use and occupation of Central Ecuador (PUGS) with the aim of proposing an environmental and territorial solution to the problems generated by the mismanagement of cemeteries, through the physicochemical analysis of soil and water and studies of land use compatibility. The results indicate the tendency of contamination caused by the studied cemeteries, since the samples taken in both the rainy and dry season for the measurement of parameters $\mathrm{BOD}_{5}, \mathrm{COD}, \mathrm{DO}, \mathrm{pH}$ and electrical conductivity fail to meet the established requirements of the Ecuadorian and international environmental regulations. In addition, land use conflicts were encountered in the cemetery grounds. It is concluded that the existing cemeteries should be subjected to more detailed environmental analysis and subsequently should be treated as security landfills in the closure and post-closure stage. Also, it has been concluded that the cemeteries should not be located in urban or peri-urban areas.
\end{abstract}

Keywords: cemeteries; polluted environment; urban planning; soil use; cadaveric decomposition; Ecuador

\section{Introduction}

Once a person dies, their body may become a potential source of contamination due to migrating leachates generated by decomposition. This becomes even more evident when the body is buried in a cemetery within an unregulated or critical location, often being close to water fountains [1,2]. Due to the sanitary problems that caused the exhumation of corpses inside churches at the beginning of the nineteenth century, the creation of cemeteries far from the urban limits of the capitals began [3]. Globally, a disturbing reality is being experienced due to rapid urbanization and environmental degradation in urban and rural areas [4-6]. As the urban sprawl increases, the disposal of human bodies becomes a critical environmental problem [7-9] as the cemetery is the main funerary form still currently used in the world [10]. However, the previous treatment of human corpses varies according to the beliefs and idiosyncrasies of each region or state, which implies a variety of different environmental effects [11]. 
The efficient management of cemeteries is a key element to control environmental, social and also ecological impacts $[12,13]$. Incompatible land uses are a major source of potential degradation at urban level. The implementation of cemeteries in residential areas is often rejected by the resident population $[14,15]$. However, the areas near the cemeteries have been inhabited, becoming residential due to urban sprawl [16,17]. Thus, these resting places imply a long-term occupation of quality soils that are a basic natural resource. Unsustainability is beginning to be felt due to the exponential increase in the human population $[9,18]$. The implementation of cemeteries has the potential to impact health and is capable of affecting suburban areas. Therefore, preventive measures and even mitigation may be necessary [19]. The inappropriate location of cemeteries causes problems and disagreements such as bad odor, risk of disease, and aesthetic impact, among others [16]. Furthermore, land use policies and planning are based on demographic projections, which are reliable for fifteen or twenty years; that is, they are transitory and are constantly evolving according to social preferences and requirements $[20,21]$. Generally, cemeteries are a requirement within a community as part of the unavoidable equipment for society and, as such, these are spaces designed and built based on the criteria and technical knowledge of a given period [22].

It takes 15 to 25 years for a human corpse to reach ideal or complete decomposition [23]. The decomposition rate of buried corpses is highly dependent on burial depth and ambient temperatures [24]. When the ambient temperature is between 16 and $20{ }^{\circ} \mathrm{C}$ the decomposition of the bodies will be accelerated, while with low temperatures, -5 to $6{ }^{\circ} \mathrm{C}$, the bodies will take longer to decompose [25]. Furthermore, soil moisture influences decomposition due to its effect on soil microbial activity, since microorganisms are the primary decomposers in soils [26]. The human body is a source of organic matter that, being in suitable environmental conditions and with the influence of scavengers, insects and decomposing microorganisms, the disintegration process could be accelerated to an estimated time of two to five years $[27,28]$. The decomposition of inhumed bodies results in leachates, typically composed of water, proteins, fats, mineral salts, and carbohydrates, and as they are not retained by vegetation they will infiltrate and are able to generate eutrophication [29,30], in addition to possible microbial pathogens, i.e., bacteria and viruses [31]. An adult human body weighing $70 \mathrm{~kg}$ generates up to $40 \mathrm{~L}$ of leachate, in other words, 0.4 to $0.6 \mathrm{~L}$ of leachate is produced per $\mathrm{kg}$ of body weight [32], which represents $62 \%$ of the mass of decomposed material [33]. Those, which are composed of $60 \%$ water, $30 \%$ mineral salts and $10 \%$ of substances such as putrescine, cadaverine and heavy metals [34], as well as chlorine and formaldehyde, which are used in funeral practices $[35,36]$, can reach groundwater and surface water. Pollution due to cemeteries is directly proportional to the size of cemeteries and the number of burials [31]. There is a potential risk that sources of drinking water may be contaminated with fecal matter from corpses. Carcasses frequently leak feces that are able to contaminate rivers or other water sources and cause intestinal diseases [37].

In European countries, physicochemical soil analyses were performed in areas near ancient cemeteries, reaching high levels of bacteriological contamination, which demonstrated the influence of cemeteries on groundwater contamination [38]. In turn, an increase in typhoid fever cases was found in people whose residence was close to the analyzed cemetery. These studies indicated that the concentration of this bacterium was sixty times higher than the concentration found in natural water detected $0.5 \mathrm{~m}$ from groundwater from the alluvial substrate, whose concentration decreased depending on the depth of the sampling [32]. In China, South Africa and Nigeria, soil quality analyses were conducted in representative cemeteries, finding contamination associated with burial practices, indicating an increase in the concentration of trace metals due to the use of coffins with painted metal ornaments or processed wood [39,40].

There is also further contamination issues within graveyards and cemeteries: excavating a modern cemetery in the United States is similar to excavating a toxic waste site [41]. Each year the bodies buried, along with chemicals and complementary materials, comprise 
a total of 30 million feet of hardwood, 2700 tons of copper and bronze, 104,272 tons of steel and 1,636,000 tons of reinforced concrete, in addition to 827,060 gallons of embalming fluid or formaldehyde [41].

In Latin America, the environmental impact caused by cemeteries was exposed, finding 35 ways they impacted upon the physical environment. These included quality of air, soil and surface water, with a percentage of $49.3 \%$ of environmental impact, and they had visibly altered the quality of water and soil in the nearby sector [42]. In addition, negative consequences were observed in the population and local commerce due to the presence of waste, sewage and sediment discharge [29]. In the soil analysis of three representative cemeteries, elevated concentrations of copper, zinc, iron, manganese, lead and chromium were found with respect to soils located outside the study area [29]. Furthermore, since 2020, there has been a global saturation of funeral services as a result of the increase in deaths during the COVID-19 pandemic. Due to contextual and socioeconomic factors, it has been difficult for Latin America to cope with this epidemic [43-45].

Based on the aforementioned information, the main objective of the current study has been to propose a solution to the environmental and territorial problems generated by the mismanagement of cemeteries located in so-called critical areas. Thus, we decided to base this proposal in central Ecuador in order to minimize the environmental impacts that are generated in the sectors surrounding the cemeteries in the chosen study area, through the analysis of previous studies, the physicochemical characterization of the water and soil in the area of study and analysis of compliance with current environmental and territorial regulations.

\section{The Local Case of Ecuador}

With the current Ecuadorian regulations in force, technical parameters are not considered which mitigate the environmental impacts caused by the decomposition of human corpses. As with land use plans, cemeteries are not regulated seriously enough considering the importance and impact they have on their location. There are few or no policies that govern them, and this causes their presence in residential areas to only be regulated by permits from the administration and under compliance with the law [46]. The regulation for funeral establishments and corpse management in Ecuador was issued in 2018 [47]. This regulation is limited to the management of corpses prior to exhumation or burial, ignoring the subsequent process, which needs a long-term analysis, including the environmental part [45]. Management policies need to be applied according to the nature and reality of each cemetery, as the treatment that needs to be given will depend on the characteristics of each area, being environmental, geographical and social [20].

Of the 72 cemeteries located in Central Ecuador, 32 were identified as poorly located as the result of a spatial analysis [48]. Hydrography criteria, soil texture, population density, slope, green areas, distance to the historic center, precipitation and temperature were introduced in a subsequent analysis, determining that there is a possibility of environmental contamination due to the equivocal location of nine cemeteries [46]. In the latter, classified as potentially polluting, a field study was performed that included determination of the water table, biochemical oxygen demand (BOD), chemical oxygen demand (COD), dissolved oxygen (DO), electrical conductivity, $\mathrm{pH}$ and temperature, furthermore, to the addition of variables such as distance to the body of water, type of soil, number of graves, age of the cemetery and geological fault. Therefore, we concluded the potential that these nine (9) graveyards are very likely sources of environmental contamination, they also lacked any completely adequate areas for the location of cemeteries [11].

Currently, Ecuador does not have an analysis of environmental parameters that allows us to know with any certainty whether or not cemeteries are sources of environmental contamination. Therefore, it is urgent to generate environmental and territorial management plans for cemeteries, which are based on technical analyses such as environmental quality standards, physical-chemical and bacteriological parameters of water and soil, electrical conductivity, exchange capacity, and infiltration rate among others. These may 
allow us to establish, in an optimal way, the determination of the carrying capacity of the cemeteries to their correct location, from planning to closure, in addition to setting the most appropriate land use for the areas near them, thus mitigating environmental impacts and health effects on the population. The situation worsened in Ecuador as in this country there has also been an excess of mortality due to COVID-19 since the beginning of 2020, like in so many other countries [49-51] The pollution generated by a cemetery is proportional to the number of graves and the age of the cemetery [11], so the cemeteries of Nanegal with approximately 500 graves, Cutuglagua with 10,000, Chillogallo with 40,000 and Pintag with 8000, are attractive for the present study, which together with other criteria such as distance to the body of water, slope, and water table among others, made these potential areas of contamination.

\section{Study Area, Materials, and Methods}

The study area focused on the cemeteries located in the central highlands of Ecuador, within the province of Pichincha. This area was selected as it is adjacent to Quito, the capital of the Republic of Ecuador, which has the second highest population density in the country [52]. There have been four specific cemeteries within three different cantons, which are particularly the cemeteries of: 1 . Nanegal; 2. Chillogallo; 3. Pintag; and 4. Cutuglagua (Figure 1). The extensions of these four sites are between 960 and approximately $9600 \mathrm{~m}^{2}$ and their nearest distance to rivers range between 2 and $143 \mathrm{~m}$. They were determined in a preliminary study as critical in environmental terms [11].

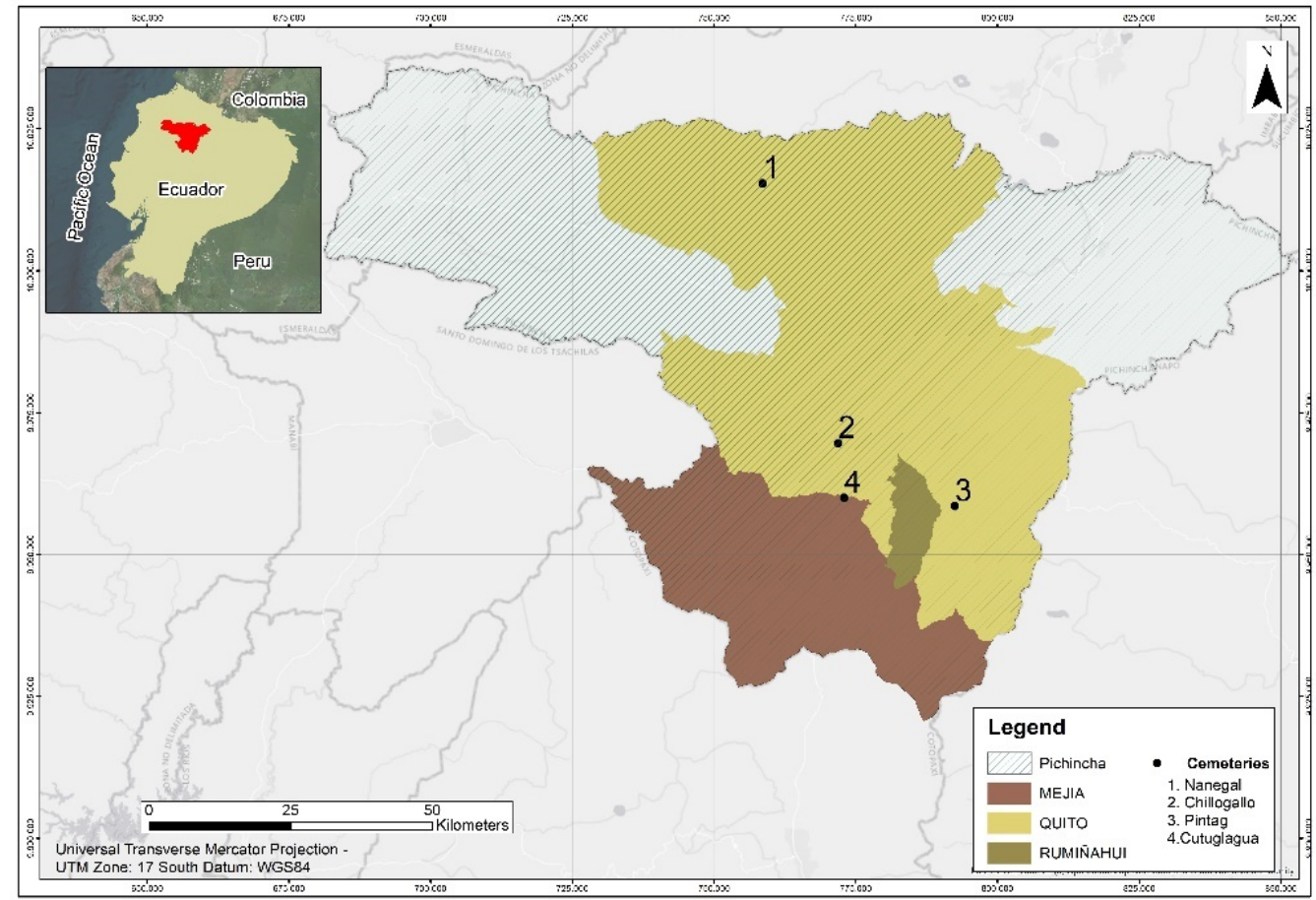

Figure 1. Inlet illustrates position of study area within Ecuador and main map locates the studied cemeteries as indicated in the corresponding legend.

The physicochemical parameters of water and soil from cemeteries Nanegal, Chillogallo and Pintag were analyzed, while we performed only soil analyses of the Cutuglagua cemetery. No analysis was performed on water samples from the Cutuglagua cemetery since it was determined that the soil in the area is silty loam, which implies that the contaminants are retained on the surface coast of the soil $[53,54]$. In the same way, a highway was found between the body of water and the slope that limits the cemetery, in addition to the inaccessibility of the sample point, so it was decided that the water sample did not contribute to the current study. 
For further control of our study, simple and random soil samples were taken in the dry season, within each cemetery for the laboratory analysis of organic matter, $\mathrm{pH}$, and electrical conductivity at three different depths, being superficial $(0.50 \mathrm{~m})$, medium $(1.50 \mathrm{~m})$ and deep $(2.50 \mathrm{~m})$ resulting to a total of 12 soil samples. We decided to take the samples at the depths mentioned above as the research team verified in the field that the maximum burial depth is $2 \mathrm{~m}$, despite the fact that the regulations dictate that burials must be at a depth of $2.5 \mathrm{~m}$. The main reason for non-compliance with the norm is the result of the norm having only been in force since 2013, whereas the cemeteries have been in operation for more than forty years. [11].

Regarding the soil parameters analyzed, all were determined in the laboratory of Universidad de las Fuerzas Armadas-ESPE in Sangolquí, Ecuador. The AS-02 method of the Mexican standard NOM-021-SEMARNAT-2000 used to determine $\mathrm{pH}$ [55]. For the determination of electrical conductivity in soils, the procedure proposed by ISO 11265.1994 Soil quality was used [56]. For both parameters, the multiparametric Hach model HQ40d and probes of the same brand whose models were CDC401 and PHC101, respectively, and duly calibrated, were used [57]. For the determination of organic matter, the loss on calcination method proposed by TMECC Method 05 July 2001 [58] was used as well as the method of Sadzawka [59]. Subsequently, a comparison was made with the Unified Text of Ecuadorian Secondary Environmental Legislation (TULAS) [60].

With regard to the data measured in soil, such as $\mathrm{pH}$, electrical conductivity and organic matter, a comparison was realized with NOM-021-SEMARNAT-2000 [61], using Canadian Soil Quality Guidelines for the Protection of Environmental and Human Health [62] and with TULAS [60].

Two series of water samples were conducted: the first being in the rainy season (June 2021) and the second during the dry season (August 2021) with a total of 30 simple random water samplings; 12 samples in the rainy season and the residual 18 samples in the dry season. Water parameters were measured in situ such as $\mathrm{DO}, \mathrm{pH}$, electrical conductivity, and temperature. In the laboratory, $\mathrm{BOD}_{5}$ and $\mathrm{COD}$ were analyzed as given control points upstream and downstream of each cemetery. All samples were taken $200 \mathrm{~m}$ upstream and downstream, (taking upstream samples as control points).

The determination of $\mathrm{BOD}_{5}$ was performed using the MAM-38/APHA 5210 B Modified test method [57]. The determination of COD was conducted using the M-GO-AM-23 assay method/Merck oxidative and colorimetric method 28, 29, 112, 132 [61]. Both tests were realized in the accredited laboratory of Central University of Ecuador. For the measurement of DO concentration, saturation percentage (\% sat), and temperature $\left({ }^{\circ} \mathrm{C}\right)$. The multiparametric Hach model HQ40d was used, calibrated and coupled with an LDO probe of the same brand and model LDO101 [57]. Electrical conductivity and pH were determined with equipment and properly calibrated Hach probes, whose models were CDC401, and PHC101, respectively.

For the territorial analysis, a comparison was performed with the Land Use Management Plan (PUGS) [63], current Ecuadorian regulations [47], preliminary studies [13] and field observations, including remote sensing, drone measurements and multi-criteria analysis $[11,48]$, thus determining the differences and limitations existing between the practice and the current territorial regulations, which are generating land use conflicts [13]. The area of Pintag, Chillogallo and Nanegal cemeteries were obtained through the metropolitan regulation report [64]. Despite the fact that Cutuglagua is included in the municipal administration of Mejía canton, the information was taken from the PUGS of Metropolitan District of Quito [63] as the PUGS of the canton it belongs to is not up to date and the cemetery is on the border with Metropolitan District of Quito.

Finally, for the analysis of land use a comparison was used, in which the PUGS was legally declared as the property of each cemetery. Therefore, according to observations made during the fieldwork, it needed to be established if there is a conflict of compatibility. 


\section{Results and Discussion}

In Figure 2a, the $\mathrm{pH}$ values of the Chillogallo, Nanegal, Pintag and Cutuglagua cemetery soil samples are illustrated, respectively. We observed that the values are outside the quality range and in turn tend to acidity [55]. On the other hand, the $\mathrm{pH}$ values obtained in the Chillogallo soil are within the quality range imposed by TULAS and Canadian Soil Quality Guidelines for the Protection of Environmental and Human Health $(6-8)[60,62]$. Similarly, it was observed that the soil tends to be neutral [55].

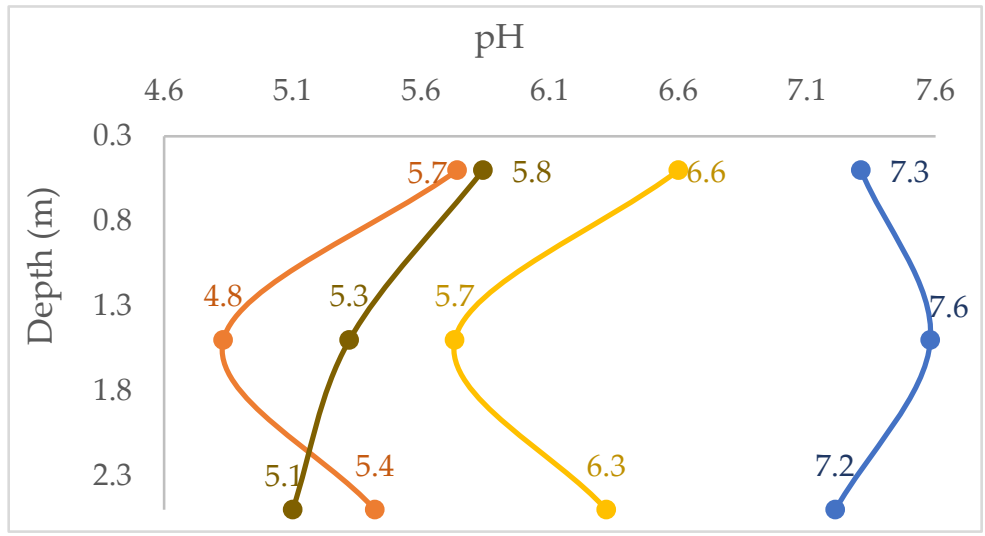

(a)

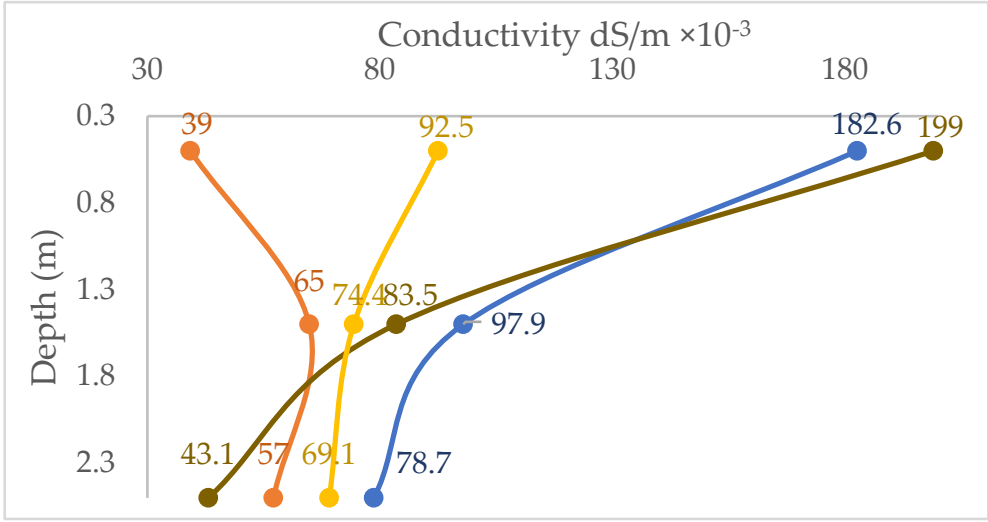

(b)

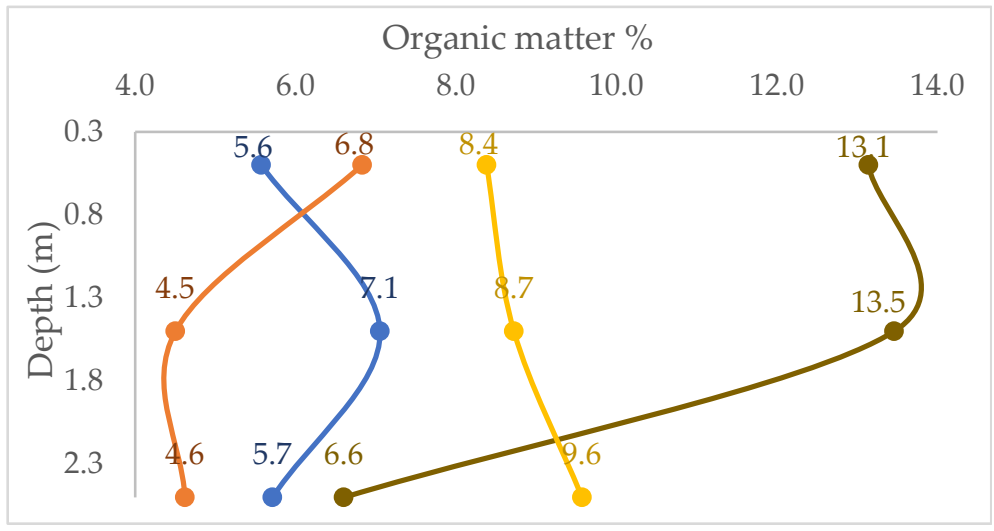

(c)

$$
\rightarrow \text { Chillogallo } \longrightarrow \text { Nanegal } \rightarrow \text { Cutuglagua } \multimap \text { Pintag }
$$

Figure 2. Physicochemical parameters of the soil samples taken in superficial profile $(0.5 \mathrm{~m})$, medium $(1.5 \mathrm{~m})$ and Deep $(2.5 \mathrm{~m}),(\mathbf{a}) \mathrm{pH},(\mathbf{b})$ electrical conductivity and (c) \% organic matter. 
The electrical conductivity values of the soil samples from the four cemeteries are presented in Figure $2 b$. These are within the permissible values for residential, commercial, industrial, and agricultural use imposed by the Ecuadorian Technical Standard [65] and Canadian Soil Quality Guidelines for the Protection of Environmental and Human Health $[62,66](2 \mathrm{dS} / \mathrm{m})$, despite the fact that the electrical conductivity values of $\mathrm{Cu}$ tuglagua and Chillogallo are at the limit of such a range.

As indicated in Figure 2c, the organic matter in the Nanegal and Cutuglagua cemeteries tend to decrease according to the depth. On the other hand, Pintag presents an increase in organic matter according to the depth of sampling and in Chillogallo constant values are observed in organic matter, except in the medium depth profile.

The soil parameters of the Nanegal and Cutuglagua cemeteries display the behavior one would expect $[67,68]$, unlike the soil of Chillogallo and Pintag. In Chillogallo, unexpected values were obtained in the physicochemical parameters in the soil sample of the medium profile where a higher percentage of organic matter and acid $\mathrm{pH}$ were observed, which rather than being attributed to the influence of the cemetery, was due to a previous movement of the soil. On the other hand, in Pintag the directly proportional increase in organic matter with respect to depth was found, and could be attributed to leachate infiltration [1].

The soils of Nanegal, Cutuglagua and Pintag tend to be acidic, except for Chillogallo, whose $\mathrm{pH}$ values together with the values of the surface and deep samples of Pintag are within the ranges established by national and international regulations [62,66]. All the soil samples analyzed presented electrical conductivity values within the established range of the Ecuadorian [66] and Canadian environmental regulations [62]. The soils have characteristics between light and moderately saline soil [55], which could affect the presence of sensitive vegetation [69].

Regarding the content of organic matter and according to the classification imposed by the Mexican regulation SERMANAT [55], the superficial and deep samples of the Chillogallo cemetery have a low content of organic matter concentration, while the medium depth sample contains an average organic matter content. The surface soil sample from the Nanegal cemetery presents a medium concentration of organic matter, unlike the medium and deep samples, which presented low content. On the other hand, the soil of the Cutuglagua cemetery presented a high content of organic matter in the superficial and medium profiles, unlike the deep profile, which indicated low concentration. The samples from the Pintag cemetery yielded medium organic matter content, with an increase in this in the deep profile, taking it to be at the limit of the medium to high classification range $(10.9 \%)$.

Table 1 documents the values obtained from the physicochemical parameters both in situ and in the laboratory of the water samples from rivers near the critical cemeteries, allowing a comparison of upstream with downstream in the dry and rainy season. The amounts in parentheses represent the standard values of the Ecuadorian legislation (TULAS) for water, except the electrical conductivity value which is a bibliographic value $[60,70]$. According to the parameters measured in situ, the water from the Alambí river, which is close to the Nanegal cemetery, has an adequate electrical conductivity value for agricultural use. However, the electrical conductivity values for the Grande and Sanguanchi rivers near the Chillogallo and Cutuglagua cemeteries, respectively, have values between 250 and $280 \mathrm{uS} / \mathrm{cm}$ of electrical conductivity. However, their use is conditioned by the type of salts they contain.

Figure 3 illustrates the averages of the BOD, COD and DO values obtained from the water samples taken near the critical cemeteries, compared with the standard value given by TULAS [61], which are equal to bibliographical references [71], for agricultural use. The values of the measured parameters $\left(\mathrm{BOD}_{5}\right.$ and $\left.\mathrm{COD}\right)$ should be higher in the dry season than in the rainy season, due to the dissolution caused by precipitation [72,73]. Even so, the opposite effect was observed in the Chillogallo cemetery, which may be attributed to anthropogenic activity (in addition to the fact that the sewage for domestic use goes directly 
to the body of water, wastes caused by the artisanal production of dairy products were observed) observed in the rainy season sampling that was conducted on Saturday from 9 to 11:30 AM, while the dry season sampling was conducted on Saturday from 4:30 to 6:00 AM.

Table 1. Physicochemical parameters obtained in samples from water bodies near critical cemeteries.

\begin{tabular}{|c|c|c|c|c|c|c|c|c|c|c|c|}
\hline \multirow{3}{*}{\multicolumn{2}{|c|}{$\begin{array}{c}\text { Cemetery: } \\
\text { Season: } \\
\text { Location Respect to Cemetery: }\end{array}$}} & \multicolumn{10}{|c|}{ Chillogallo } \\
\hline & & \multicolumn{4}{|c|}{ Rainy $\mathrm{n}=4$} & \multicolumn{6}{|c|}{ Dry $n=6$} \\
\hline & & \multicolumn{2}{|c|}{ Upstream } & \multicolumn{2}{|c|}{ Downstream } & \multicolumn{3}{|c|}{ Upstream } & \multicolumn{3}{|c|}{ Downstream } \\
\hline \multirow{5}{*}{ Parameter } & $\mathrm{pH}(6-9)$ & 7.4 & 7.05 & 7.05 & 7.16 & 7.45 & 7.7 & 7.8 & 6.2 & 7.78 & 7.86 \\
\hline & Cond. us/cm (280) & 399 & 170.6 & 962 & 183.2 & 252 & 253 & 268 & 249 & 289 & 302 \\
\hline & $\mathrm{DO} \mathrm{mg} / \mathrm{L}(5)$ & 4.75 & 6.75 & 4.34 & 7.04 & 6.97 & 6.88 & 6.8 & 6.45 & 6.43 & 6.44 \\
\hline & $\mathrm{BOD}_{5} \mathrm{mg} / \mathrm{L}(20)$ & 77 & 20 & 163 & 10 & 14 & 14 & 17 & 16 & 20 & 28 \\
\hline & COD mg/L (40) & 141 & 26 & 266 & 68 & 36 & 31 & 41 & 54 & 51 & 51 \\
\hline \multicolumn{2}{|c|}{ Cemetery: } & \multicolumn{10}{|c|}{ Nanegal } \\
\hline & Season: & \multicolumn{4}{|c|}{ Rainy $n=4$} & \multicolumn{6}{|c|}{ Dry $n=6$} \\
\hline \multicolumn{2}{|c|}{ Location Respect to Cemetery: } & \multicolumn{2}{|c|}{ Upstream } & \multicolumn{2}{|c|}{ Downstream } & \multicolumn{3}{|c|}{ Upstream } & \multicolumn{3}{|c|}{ Downstream } \\
\hline \multirow{5}{*}{ Parameter: } & $\mathrm{pH}(6-9)$ & 6.86 & 6.5 & 7.01 & 6.48 & 7.15 & 7.28 & 7.33 & 7.27 & 7.42 & 7.42 \\
\hline & Cond. us/cm (280) & 73.9 & 106.45 & 71.1 & 103.04 & 125.6 & 123.4 & 114 & 114.9 & 110.6 & 120.8 \\
\hline & $\mathrm{DO} \mathrm{mg} / \mathrm{L}(5)$ & 7.71 & 8.3 & 7.97 & 8.12 & 8.16 & 8.31 & 7.74 & 8.02 & 8.3 & 7.99 \\
\hline & $\mathrm{BOD}_{5} \mathrm{mg} / \mathrm{L}(20)$ & $<5$ & $<5$ & $<5$ & 7 & $<5$ & $<5$ & $<5$ & $<5$ & $<5$ & 7 \\
\hline & COD mg/L (40) & $<8$ & $<8$ & $<8$ & 57 & 14 & $<8$ & 18 & 19 & $<8$ & 51 \\
\hline \multicolumn{2}{|c|}{ Cemetery } & \multicolumn{10}{|c|}{ Cutuglagua } \\
\hline & Season: & \multicolumn{4}{|c|}{ Rainy $n=4$} & \multicolumn{6}{|c|}{ Dry $n=6$} \\
\hline \multicolumn{2}{|c|}{ Location Respect to Cemetery } & \multicolumn{2}{|c|}{ Upstream } & \multicolumn{2}{|c|}{ Downstream } & \multicolumn{3}{|c|}{ Upstream } & \multicolumn{3}{|c|}{ Downstream } \\
\hline \multirow{5}{*}{ Parameter: } & $\mathrm{pH}(6-9)$ & 6.87 & 6.6 & 7.11 & 6.9 & 7.19 & 6.84 & 7.2 & 7.33 & 7.37 & 7.3 \\
\hline & Cond. us/cm (280) & 273 & 228 & 283 & 223 & 246 & 250 & 255 & 247 & 260 & 257 \\
\hline & $\mathrm{DO} \mathrm{mg} / \mathrm{L}(5)$ & 4.78 & 5.74 & 5.81 & 6.5 & 4.61 & 4.61 & 4.72 & 5.74 & 5.77 & 5.86 \\
\hline & $\mathrm{BOD}_{5} \mathrm{mg} / \mathrm{L}(20)$ & 34 & 19 & 33 & 21 & 33 & 31 & 31 & 28 & 26 & 27 \\
\hline & COD mg/L (40) & 75 & 46 & 57 & 68 & 65 & 86 & 71 & 46 & 47 & 51 \\
\hline
\end{tabular}

The values obtained from the samples from the Chillogallo cemetery in the dry season may be the most representative for this research, since they were sampled at dawn to eliminate the possible anthropogenic interferences detected in the sampling during the rainy season. Even so, it was not possible to eliminate the interference generated by the existence of a discharge pipe at the height of the upstream sample point. This implies that the contamination expelled from such an installation would not be homogenized at the time the sample was taken, which explains the higher pollution values upstream compared to downstream, which is observed in Figure 3d.

The water from the Alambí (Nanegal) river can be used for all the uses silver plated by the TULAS [60] except for human and domestic consumption. The $\mathrm{BOD}_{5}$ values in the C.hillogallo and Cutuglagua water bodies do not meet quality parameters for any use. The difference between the upstream and downstream COD ranges can only be observed in the body of water near the Nanegal cemetery, which ranges from excellent quality upstream to acceptable downstream in the rainy season. In the dry season it passes from good to acceptable quality. The ranges used are those established by SERMANAT [60]. 


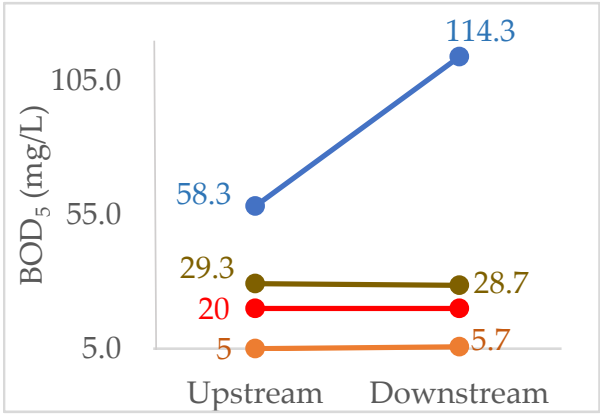

(a)

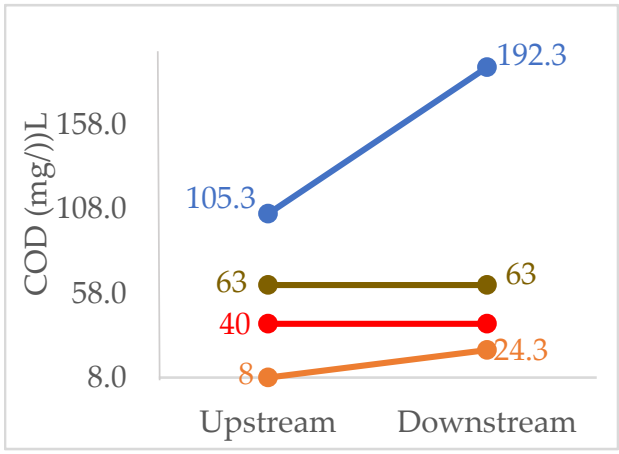

(c)

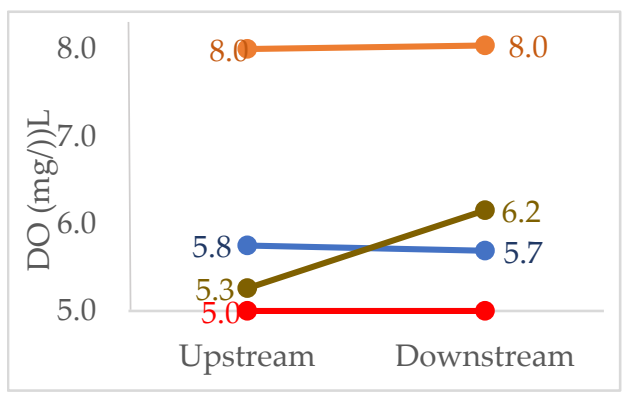

(e)

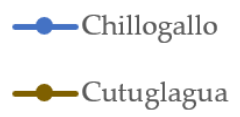

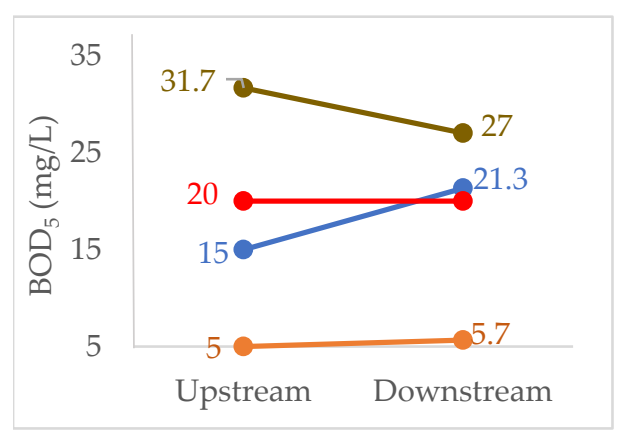

(b)

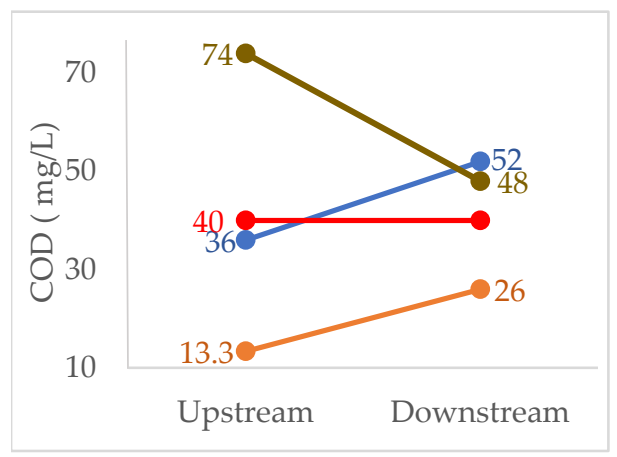

(d)

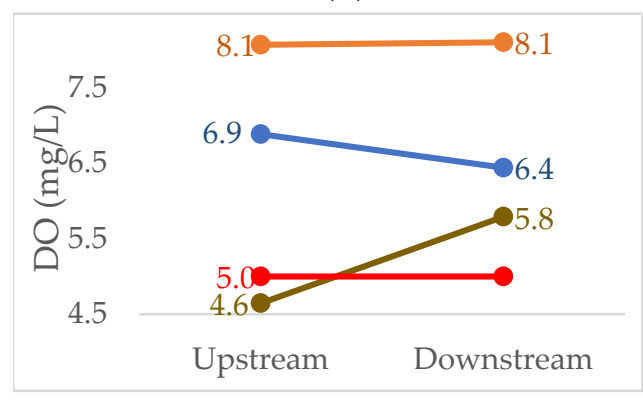

$(\mathbf{f})$

Figure 3. Comparison of $\mathrm{BOD}_{5}, \mathrm{COD}, \mathrm{DO}$ values obtained in water samples taken before and after critical cemeteries in the rainy season $(\mathbf{a}, \mathbf{c}, \mathbf{e})$ and the dry season $(\mathbf{b}, \mathbf{d}, \mathbf{f})$.

Although the water from the Chillogallo and Cutuglagua rivers are used for agricultural use, further analysis is required to determine if this use is adequate, since, due to the values obtained for electrical conductivity, $\mathrm{BOD}_{5}$ and $\mathrm{COD}$ initially in this investigation, they indicate these bodies of water have a high level of contamination compared to the limit value imposed in the TULAS [60]. In the samples of the body of water near the Cutuglagua cemetery, it was observed that in the rainy season the values tend to be constant and in the dry season the values of $\mathrm{BOD}_{5}$ and $\mathrm{COD}$ decrease. This could be attributed to the self-cleaning nature of the water since the sample was taken $200 \mathrm{~m}$ downstream, where the water's path witnessed rocks and vegetation, allowing the oxygenation process with the hit of the water current $[74,75]$. Therefore, it could not be confirmed that the existing contamination of the river is due to the influence of the cemetery. On the other hand, the Chillogallo and Nanegal cemeteries demonstrate an increase in electrical conductivity, $\mathrm{BOD}_{5}$ and $\mathrm{COD}$ values, which could be attributed to the filtration of pollutants from those cemeteries.

Furthermore, a land use conflict was documented in the Chillogallo cemetery, since the PUGS establishes the prohibition of low-impact industrial economic activity in that area. 
Hereby, a discharge of dairy waste was observed in the field and the existence of a park neighborhood $20 \mathrm{~m}$ away, which is in conflict as the PUGS [63] rules that neighborhoodscale facilities have a radius of influence and coverage between 400 and $800 \mathrm{~m}$.

In the Pintag cemetery, a conflict was encountered with the restriction for religious establishments since the PUGS establishes a maximum capacity of 500 people in the church However, the main church in the sector is located a few meters from the cemetery and has a greater influx than that established in days of holidays and other festivities. Both, Nanegal and Cutuglagua, do not present compatibility conflict imposed by the PUGS. Although the cemeteries were created before the new PUGS guidelines were issued, nowadays none meet the minimum area established for the implementation of cemeteries, which is of about $20,000 \mathrm{~m}^{2}$ zonal cemeteries and $50,000 \mathrm{~m}^{2}$ metropolitan cemeteries [63]. However, no regulations or legislation were found in force that restrict or regulate the construction of houses or equipment near cemeteries. None of the cemeteries studied meets the minimum required distance of $200 \mathrm{~m}$ to any body of water [47].

The results of the environmental analyses obtained indicate a trend towards environmental contamination caused by cemeteries, and therefore, all existing or planned cemeteries must have a radial buffer zone with native vegetation of the place; the same one that retains the pollutants of the infiltrated leachates. The radius of the buffer zone will depend on the needs of the sector [76-78]. Cemeteries that have critical characteristics [48] with a notable tendency for contamination or saturation, and those located in urban or residential sectors that do not have a buffer zone should be treated as a security landfill in the closure phase. Furthermore, post-closure protocols [79] should be applied with the environmental monitoring required by this type of establishment [80]. The use of land equipment may only be close to the cemetery in the event of the existence of the buffer zone or, failing that, being the buffer zone as long as it has the necessary amount and species of vegetation to avoid affecting the health of the population or the environmental quality of the sector. Cemeteries should not be implemented in urban or peri-urban areas [81]. The creation and use of sustainable alternatives such as green cemeteries [39], which can be located in multifunctional land uses [82], should be promoted. The circular economy can be incurred by using the skeleton of tombs that have been abandoned for more than ten years in the industry as a source of catalyst providing economic benefits and environmental protection, thus reducing dependence on non-renewable natural resources [83].

\section{Conclusions}

The values obtained in the physicochemical analyses of soil and water reveal that the cemeteries analyzed in this study, except Cutuglagua, could be potential sources of environmental contamination. Therefore, a more exhaustive analysis of environmental parameters would be required and, if contamination is confirmed, they should be treated as landfills in closure and post-closure stages. For the construction of new cemeteries, it must be ensured that environmental, territorial, and geographical criteria are met for proper implementation.

Land uses change according to the development of the population in conjunction with urban sprawl, which implies that cemeteries that were once considered to be in rural areas are now in urban areas; ones that could be converted and represent a risk to the health of the inhabitants of the surrounding sectors. Cemeteries should not be implanted in urban or peri-urban areas due to the generation of conflicts in the compatibility of land use.

Author Contributions: Conceptualization, G.F.G. and T.C.-P.; methodology, T.C.-P.; software, G.F.G.; validation, P.G.-G. and G.F.-N.; formal analysis, G.F.G., T.C.-P. and I.S.-G. investigation, G.F.G., T.C.-P., T.T., G.F.-N., P.G.-G., E.M.-L., D.V.-F., E.S. and I.S.-G.; resources, G.F.G., T.C.-P., T.T., G.F.-N., P.G.-G., E.M.-L., D.V.-F., E.S. and I.S.-G.; data curation, G.F.-N. and P.G.-G.; writing-original draft preparation, G.F.G. and T.C.-P.; writing-review and editing, G.F.G., T.C.-P., T.T. and P.G.-G.; visualization, T.T., G.F.-N., P.G.-G., E.M.-L., D.V.-F., E.S. and I.S.-G.; supervision, T.T., G.F.-N., P.G.-G., E.M.-L., D.V.-F., E.S. and I.S.-G.; project administration, T.C.-P.; funding acquisition, G.F.G.; T.C.-P. and I.S.-G. investigation, 
G.F.G., T.C.-P., T.T., G.F.-N., P.G.-G., E.M.-L., D.V.-F., E.S. and I.S.-G. All authors have read and agreed to the published version of the manuscript.

Funding: This research received no external funding.

Institutional Review Board Statement: Not applicable.

Informed Consent Statement: Not applicable for studies not involving humans.

Data Availability Statement: Not applicable.

Conflicts of Interest: The authors declare no conflict of interest.

\section{References}

1. Velasco Rivera, A.; Minota Zea, Y.M. Evaluación por contaminación en suelos aledaños a los cementerios Jardines del Recuerdo e Inmaculada. Cienc. E Ing. Neogranadina 2012, 22, 165. [CrossRef]

2. Zychowski, J. Impact of cemeteries on groundwater chemistry: A review. Catena 2012, 93, 29-37. [CrossRef]

3. Planteamientos y acciones en materia de higiene pública: Los cementerios de la ciudad de México a principios del siglo diecinueve. Rev. Cult. Y Reli. 2008, 2, 60-81. Available online: https://revistaculturayreligion.cl/index.php/revistaculturayreligion/article/ view/182/1712 (accessed on 21 October 2021).

4. Hugo, G. Future demographic change and its interactions with migration and climate change. Glob. Environ. Chang. 2011, 21 (Suppl. 1), S21-S33. [CrossRef]

5. McDonald, R.I.; Marcotullio, P.J.; Güneralp, B. Urbanization and global trends in biodiversity and ecosystem services. In Urbanization, Biodiversity and Ecosystem Services: Challenges and Opportunities: A Global Assessment; Springer Nature: Basingstoke, UK, 2013; pp. 31-52. ISBN 9789400770881.

6. Allén, A. La interfase periurbana como escenario de cambio y acción hacia la sustentabilidad del desarrollo. Cuad. CENDES 2003, 20,7-21. Available online: http:/ / ve.scielo.org/scielo.php?pid=S1012-25082003000200002\&script=sci_arttext (accessed on 4 November 2021).

7. Canning, L.; Szmigin, I. Death and disposal: The universal, environmental dilemma. J. Mark. Manag. 2010, $26,1129-1142$. [CrossRef]

8. Nguyen, T.; Nguyen, L. Groundwater pollution by longstanding cemetery and solutions for urban cemetery planning in Ho Chi Minh City-From reality to solutions. In MATEC Web of Conferences; EDP Sciences: Les Ulis, France, 2018; Volume 193, p. 02008. [CrossRef]

9. Scalenghe, R.; Pantani, O.L. Connecting existing cemeteries saving good soils (for livings). Sustainability 2020, 12, 93. [CrossRef]

10. da Cruz, N.J.T.; Lezana, Á.G.R.; Freire dos Santos, P.D.C.; Santana Pinto, I.M.B.; Zancan, C.; Silva de Souza, G.H. Environmental impacts caused by cemeteries and crematoria, new funeral technologies, and preferences of the Northeastern and Southern Brazilian population as for the funeral process. Environ. Sci. Pollut. Res. 2017, 24, 24121-24134. [CrossRef] [PubMed]

11. Guayasamín Vergara, J.D. Establecimiento De Índices Empíricos Ambientales Para Manejo De Cadáveres Humanos: Entierro Y Cremación En Ecuador. Master's Thesis, Universidad de las Fuerzas Armadas ESPE, Sangolquí, Ecuador, 2021.

12. Niţă, M.R.; Iojă, I.C.; Rozylowicz, L.; Onose, D.A.; Tudor, A.C. Land use consequences of the evolution of cemeteries in the Bucharest Metropolitan Area. J. Environ. Plan. Manag. 2014, 57, 1066-1082. [CrossRef]

13. Nguyen, X.L.; Chou, T.Y.; Hoang, T.V.; Fang, Y.M.; Nguyen, Q.H. Research on Optimal Cemetery Location Selection using Approach of Fuzzy Set Theory and Analytic Hierarchy Process in Environment of Geographic Information System: A Case Study in Hung Ha District, pages 1-9 Thai Binh province, Vietnam. Int. J. Res. Innov. Earth Sci. 2019, 6, 20-28.

14. Baden, B.M.; Coursey, D.L. The locality of waste sites within the city of Chicago: A demographic, social, and economic analysis. Resour. Energy Econ. 2002, 24, 53-93. [CrossRef]

15. Neckel, A.; Korcelski, C.; Kujawa, H.A.; Schaefer da Silva, I.; Prezoto, F.; Walker Amorin, A.L.; Maculan, L.S.; Gonçalves, A.C.; Bodah, E.T.; Bodah, B.W.; et al. Hazardous elements in the soil of urban cemeteries; constructive solutions aimed at sustainability. Chemosphere 2021, 262, 128248. [CrossRef] [PubMed]

16. Tudor, C.A.; Iojă, I.C.; Hersperger, A.; Pătru-Stupariu, I. Is the residential land use incompatible with cemeteries location? Assessing the attitudes of urban residents. Carpathian J. Earth Environ. Sci. 2013, 8, 153-162.

17. Schneider, A.; Mertes, C.M.; Tatem, A.J.; Tan, B.; Sulla-Menashe, D.; Graves, S.J.; Patel, N.N.; Horton, J.A.; Gaughan, A.E.; Rollo, J.T.; et al. A new urban landscape in East-Southeast Asia, 2000-2010. Environ. Res. Lett. 2015, 10, 034002. [CrossRef]

18. Fistola, R. The unsustainable city. Urban entropy and social capital: The needing of a new urban planning. Procedia Eng. 2011, 21, 976-984. [CrossRef]

19. Peluso, F.; Vives, L.; Varni, M.; Cazenave, G.; González Castelain, J.; Usunoff, E. Evaluación preventiva espacial del riesgo sanitario por la instalación de un cementerio parque. GeoFocus. Rev. Int. De Cienc. Y Tecnol. De La Inf. Geográfica 2006, 6, 1-14.

20. Larkin, M.T. An Analysis of Land Use Planning Policies for Cemeteries in Ontario. Master's Thesis, Ryerson University, Toronto, ON, Canada, 2011.

21. Liang, X.; Liu, X.; Li, D.; Zhao, H.; Chen, G. Urban growth simulation by incorporating planning policies into a CA-based future land-use simulation model. Int. J. Geogr. Inf. Sci. 2018, 32, 2294-2316. [CrossRef] 
22. Fernández, M.L.; Asís, O.; Turturro, C. Los cementerios territorios de memoria urbana e identidad. J. Chem. Inf. Model. 2013, 53, 1689-1699.

23. Fiedler, S.; Graw, M. Decomposition of buried corpses, with special reference to the formation of adipocere. Naturwissenschaften 2003, 90, 291-300. [CrossRef]

24. Rodriguez, W.C.; Bass, W.M. Decomposition of Buried Bodies and Methods That May Aid in Their Location. J. Forensic Sci. 1985, 30, 11017J. [CrossRef]

25. Casper, J.L.; William Balfour, G. A Handbook of the Practice of Forensic Medicine, Based upon Personal Experience; Balfour, G.W., Translator; New Sydenham Society: London, UK, 1989; Volume 1, pp. 36-45. ISBN 1376611694.

26. Carter, D.O.; Yellowlees, D.; Tibbett, M. Moisture can be the dominant environmental parameter governing cadaver decomposition in soil. Forensic Sci. Int. 2010, 200, 60-66. [CrossRef] [PubMed]

27. Mego Julca, G. Descomposición Cadavérica y Determinación del Intervalo Post-Mortem. Skopein 2016, 12, 5. Available online: https:/ / dialnet.unirioja.es/servlet/articulo?codigo=5559749\&info=resumen\&idioma=SPA12,5 (accessed on 25 October 2021).

28. Schroeder, H.; Klotzbach, H.; Oesterhelweg, L.; Püschel, K. Larder beetles (Coleoptera, Dermestidae) as an accelerating factor for decomposition of a human corpse. Forensic Sci. Int. 2002, 127, 231-236. [CrossRef]

29. Neckel, A.; Costa, C.; Mario, D.N.; Sabadin, C.E.S.; Bodah, E.T. Environmental damage and public health threat caused by cemeteries: A proposal of ideal cemeteries for the growing urban sprawl. Urbe 2017, 9, 216-230. [CrossRef]

30. Scottish Environment Protection Agency Land Use Planning System SEPA Guidance Note Guidance on Assessing the Impacts of Cemeteries on Groundwater Uncontrolled Document When Printed Out. 2015. Available online: http://map.sepa.org.uk/ floodmap/map.htm (accessed on 9 April 2021).

31. Aroha, M.; Michele, W. Cemetery Setback Distance To Prevent Surface Water Contamination. Natl. Collab. Cent. Environ. Health 2017, 2-7. Available online: https://ncceh.ca/sites/default/files/Cemetery_setback_distances_surface_water_contaminationOct_2017.pdf (accessed on 25 October 2021).

32. Zychowski, J.; Bryndal, T. Impact of cemeteries on groundwater contamination by bacteria and viruses-A review. J. Water Health 2015, 13, 285-301. [CrossRef]

33. Turner, B.L.; Haygarth, P.M. Phosphorus Forms and Concentrations in Leachate under Four Grassland Soil Types. Soil Sci. Soc. Am. J. 2000, 64, 1090-1099. [CrossRef]

34. Neckel, A.; Korcelski, C.; Silva, L.F.O.; Kujawa, H.A.; Bodah, B.W.; Figueiredo, A.M.R.; Maculan, L.S.; Gonçalves, A.C.; Bodah, E.T.; Moro, L.D. Metals in the soil of urban cemeteries in Carazinho (South Brazil) in view of the increase in deaths from COVID-19: Projects for cemeteries to mitigate environmental impacts. Environ. Dev. Sustain. 2021, 1-24. [CrossRef]

35. Eche, J.J.E. Evaluación de impacto ambiental de un cementerio tipo parque ecológico. Rev. Del Inst. De Investig. De La Fac. De Ing. Geológica Min. Met. Y Geográfica 2012, 4, 53-58. [CrossRef]

36. Sumino, K.; Hayakawa, K.; Shibata, T.; Kitamura, S. Heavy metals in normal japanese tissues. Arch. Environ. Health 1975, 30, 487-494. [CrossRef]

37. Organización Panamericana de la Salud. La Gestión De Cadáveres En Situaciones De Desastres, 6th ed.; Morgan, O., Tidball-Binz, M., Alphen, D.V., Eds.; Organización Panamericana de la Salud: Washington, DC, USA, 2017; ISBN 9275326304I.

38. Rodrigues, L.; Pacheco, A. Groundwater contamination from cemeteries cases of study. In Proceedings of the Environmental 2010: Situation and Perspectives for the European Union, Porto, Portugal, 6-10 May 2003; Available online: http:/ / www.waylandwells. info/wp-content/uploads/2012/07/Groundwater-Contamination-from-Cemeteries-Case-Studies-2010.pdf (accessed on 13 October 2021).

39. Aruomero, A.S.; Afolabi, O. Comparative assessment of trace metals in soils associated with casket burials: Towards implementing green burials. EJSS 2014, 3, 65. [CrossRef]

40. Jonker, C.; Olivier, J. Mineral Contamination from Cemetery Soils: Case Study of Zandfontein Cemetery, South Africa. Int. J. Environ. Res. Public Health 2012, 9, 511-520. [CrossRef] [PubMed]

41. Harker, A. Landscapes of the dead: An argument for conservation burial. Berkeley Plan. J. 2012, 25, 150-159. [CrossRef]

42. Velasquez Viza, O.A. Evaluación Del Impacto Ambiental De Los Residuos Sólidos Generados En El Cementerio Del Distrito De Paucarcolla. Master's Thesis, Universidad Nacional del Altiplano, Puno, Peru, 2019.

43. Garcia, P.J.; Alarcón, A.; Bayer, A.; Buss, P.; Guerra, G.; Ribeiro, H.; Rojas, K.; Saenz, R.; de Snyder, N.S.; Solimano, G.; et al. COVID-19 Response in Latin America. Am. J. Trop. Med. Hyg. 2020, 103, 1765-1772. [CrossRef] [PubMed]

44. Huamaní, N.; Orosco, J. Análisis Comparativo Y Proyección Por Millón De Habitantes De. Ciecia Y Tecnol. 2021, $37,37-44$.

45. Ministerio De Salud Pública Ministra De Salud Confirma Muerte De Paciente Por COVID-19. Ministerio De Salud Pública Del Ecuador. 2020. Available online: https://www.salud.gob.ec/ministra-de-salud-confirma-muerte-de-paciente-por-covid-19/ (accessed on 17 October 2021).

46. Ministerio de Salud Pública del Ecuador. Reglamento Para Regular El Funcionamiento De Los Establecimientos Que Prestan Servicios Funerarios Y De Manejo De Cadáveres Y Restos Humanos; Estado de Ecuador: Quito, Ecuador, 2013; pp. 1-15.

47. Ministerio de Salud Pública. Acuerdo Ministerial No. 192: Reglamento Para Establecimientos De Servicios Funerarios Y Manejo De Cadaveres; Estado de Ecuador: Quito, Ecuador, 2018; p. 13.

48. Arcos Yánez, E.S. Identificación De Zonas Ambientalmente No Adecuadas Para La Ubicación De Camposantos En Los Cantones Mejía, Quito y Rumiñahui; Universidad de las Fuerzas Armdas “ESPE”: Sangolquí, Ecuador, 2020. 
49. Instituto Nacional De Estadísticas Y Censos Registro Estadístico De Defunciones Generales 2019. 2020. Available online: www.ecuadorencifras.gob.ec (accessed on 17 October 2021).

50. Instituto Nacional de Estadísticas y Censos Boletín Técnico Registro Estadístico de Defunciones Generales 2020. 2021. Available online: https://www.ecuadorencifras.gob.ec/institucional/ (accessed on 17 October 2021).

51. Toulkeridis, T.; Seqqat, R.; Arias, M.T.; Salazar-Martinez, R.; Ortiz-Prado, E.; Chunga, S.; Vizuete, K.; Heredia-R, M.; Debut, A. Volcanic ash as a precursor for SARS-CoV-2 infection among susceptible populations in Ecuador: A satellite Imaging and excess mortality-based analysis. Disaster Med. Public Health Prep. 2021, 1-13. [CrossRef]

52. Quitocómovamos Información Sobre Demografía Quito Como Vamos 2020 Demografía Crecimiento Poblacional Y Expansión Rural Densidad Poblacional Población Por Sexo Y Edad. Available online: https:/ / quitocomovamos.org/wp-content/uploads / 2021/05/1.DEMOGRAFÍA.pdf (accessed on 28 December 2021).

53. Durães, N.; Novo, L.A.B.; Candeias, C.; Da Silva, E.F. Distribution, transport and fate of pollutants. In Soil Pollution: From Monitoring to Remediation; Academic Press: Cambridge, MA, USA, 2017; pp. 29-57. ISBN 9780128498736.

54. Cantarero, L.; Méndez, D. Evaluación De Pavimentos De Adoquín En Vías Rurales De Nicaragua; Universidad Nacional De Ingenieria Recinto Universitario Pedro Arauz: Managua, Nicaragua, 2003.

55. Norma Oficial Mexicana. NOM-021-SEMARNAT-2000 que establece las especificaciones de fertilidad, salinidad y clasificación de suelos, estudio, muestreo y análisis. D. Ofical La Fed. 2002, 85. Available online: https://www.scienceopen.com/document?vid= 52610ad1-f53c-437b-9190-fc5025bafd93 (accessed on 28 December 2021).

56. ISO 11265:1994(E); Soil Quality—Determination of the Specific Electrical Conductivity. Technical Committee ISO: Geneva, Switzerland, 1996. Available online: https://www.iso.org/obp/ui/\#iso:std:iso:11265:ed-1:v1:en(accessed on 4 October 2021).

57. Brandi, J.; Wilson-Wilde, L. Standard Methods. In Encyclopedia of Forensic Sciences, 23rd ed.; Baird, R., Eaton, A., Rice, E., Eds.; Elsevier: Amsterdam, The Netherlands, 2013; pp. 522-527. ISBN 9780123821652.

58. TMECC Method 05.07. Organic and Biological Properties 05.06 Odor. Quality. 2001. Available online: http://www.colinst.com (accessed on 4 October 2021).

59. Sadzawka, A.; María, A.; Carrasco, R.; Grez, R. Métodos De Análisis De Compost Revisión 2005; Centro Regional de Investigación La Platina SERIE ACTAS INIA-No 30: Satiago, Chile, 2005.

60. Ministerio de Salud Pública del Ecuador. Texto Unificado de Legislación Ambiental Secundaria; Libro VI: Calidad Ambiental; Estado de Ecuador: Quito, Ecuador, 2014; pp. 1-477.

61. American Public Health Association; American Water Works Association; Water Pollution Control Federation. Métodos Normalizados Para El Análisis De Aguas Potables Y Residuales; Franson, M.A., Ed.; Ediciones Díaz de Santos: Mexico City, Mexico, 2013; Volume 53, ISBN 9788578110796.

62. Canadian Council of Ministers of the Environment Canadian Soil Quality Guidelines for the Protection of Environmental and Human Health-Canadian Environmental Quality Guidelines. 1999. Available online: http:/ /www.ccme.ca/publications/ceqg_ rcqe.html?category_id=125 (accessed on 14 January 2022).

63. Municipio Del Distrito Metropolitano De Quito Plan De Uso Y Gestión Del Suelo 2020-2030. 2020. Available online: http: //www.quitoinforma.gob.ec/2021/08/18/listo-el-plan-de-uso-y-gestion-de-suelo-para-quito/ (accessed on 23 October 2021).

64. Municipio Del Distrito Metropolitano De Quito Informe De Regulación Metropolitana. Available online: https://pam.quito.gob. ec/mdmq_web_irm/irm/buscarPredio.jsf (accessed on 19 November 2021).

65. Tulsma norma de calidad ambiental del recurso suelo y criterios de remediación para suelos contaminados. Tabla 3-Criterios de Remediación Restauración (Uso Agrícola). In REFORMA TEXTO UNIFICADO Legis. Secund. MEDIO Ambient. Libr. VI, Anexo 2, Decreto Ejec. 3516; Estado de Ecuador: Quito, Ecuador, 2015.

66. Municipio del Distrito Metropolitano de Quito Norma Técnica de la Ordenanza Metropolitana N ${ }^{\circ} 404-R e s o l u c i o ́ n ~ N^{\circ}$ 002-2014-SA 2014; Estado de Ecuador: Quito, Ecuador, 2014; pp. 1-76.

67. Kempen, B.; Brus, D.J.; Stoorvogel, J.J. Three-dimensional mapping of soil organic matter content using soil type-specific depth functions. Geoderma 2011, 162, 107-123. [CrossRef]

68. Chen, C.; Leinweber, P.; Eckhardt, K.U.; Sparks, D.L. The composition and stability of clay-associated organic matter along a soil profile. Soil Syst. 2018, 2, 16. [CrossRef]

69. Sierra, C. El pH del Suelo. D. El Mercur. 2017, 1-10. Available online: https://hgic.clemson.edu/factsheet/cambiando-el-ph-delsuelo/ (accessed on 14 September 2021).

70. Castellanos, J.Z. Guía para la interpretación del análisis de suelo y agua. Intagri 2010, 20. Available online: https://www.intagri. com/public_files/Interpretacion-de-Analisis-de-Suelos-y-Aguas.pdf (accessed on 14 September 2021).

71. Sharma, R.K.; Gulati, S. Water Quality Issues and Solutions in India. In Comprehensive Water Quality and Purification; Elsevier Inc.: Amsterdam, The Netherlands, 2014; Volume 1, pp. 21-39. ISBN 9780123821836.

72. Olías, M.; Nieto, J.M.; Sarmiento, A.M.; Cerón, J.C.; Cánovas, C.R. Seasonal water quality variations in a river affected by acid mine drainage: The Odiel River (South West Spain). Sci. Total Environ. 2004, 333, 267-281. [CrossRef] [PubMed]

73. Dietz, M.E.; Clausen, J.C. A field evaluation of rain garden flow and pollutant treatment. Water Air Soil Pollut. 2005, 167, 123-138. [CrossRef]

74. Ostroumov, S.A. On some issues of maintaining water quality and self-purification. Water Resour. 2005, 32, 305-313. [CrossRef]

75. Wei, G.L.; Yang, Z.F.; Cui, B.S.; Li, B.; Chen, H.; Bai, J.H.; Dong, S.K. Impact of dam construction on water quality and water self-purification capacity of the Lancang River, China. Water Resour. Manag. 2009, 23, 1763-1780. [CrossRef] 
76. Jones, D.L.; Williamson, K.L.; Owen, A.G. Phytoremediation of landfill leachate. Waste Manag. 2006, 26, 825-837. [CrossRef] [PubMed]

77. Seo, B.H.; Kim, H.S.; Kuppusamy, S.; Kim, K.H.; Kim, K.R. Enhanced nitrogen and phosphorus removal by woody plants with deep-planting technique for the potential environmental management of carcass burial sites. Sustainability 2017, 9, 155. [CrossRef]

78. Yoon, J.H.; Kim, Y.N.; Shin, D.C.; Kim, K.R.; Kim, K.H. Management of animal carcass disposal sites using a biochar permeable reactive barrier and fast growth tree (populus euramericana): A field study in Korea. Sustainability 2017, 9, 457. [CrossRef]

79. Autie, J.; Saanie, T.; Telppanen, P. Assessment of Alternative Disposal Concepts; U.S. Department of Energy Office of Scientific and Technical Information: Washington, DC, USA, 1996; Volume 30, ISBN 9516520111.

80. Amaya, L.G.d.C.; Marcel, S.N.; Susana, L. Cierre, sellado y reinserción de antiguos vertederos. experiencias en iberoamérica. Rev. Int. Contam. Ambient. 2016, 32, 123-139. [CrossRef]

81. Lara Galindo, E.; Zulaica, L.; Flores Domínguez, Á.D. Aportes Conceptuales Y Metodológicos Para La Definición Y Análisis Del Periurbano De La Ciudad De Puebla, México. Rev. Estud. Marítimos Y Soc. 2019, 14, 12-34. Available online: https: / / ri.conicet.gov.ar/handle/11336/121513 (accessed on 25 November 2021).

82. Yarwood, R.; Sidaway, J.D.; Kelly, C.; Stillwell, S. Sustainable deathstyles? The geography of green burials in Britain. Geogr. J. 2015, 181, 172-184. [CrossRef]

83. Hart, A. Circular economy: Closing the catalyst loop with metal reclamation from spent catalysts, industrial waste, waste shells and animal bones. Biomass Convers. Biorefinery 2021, 1-16. [CrossRef] 